\title{
Вибір зразка озброєння на основі нечіткої логіки в заходах оборонного менеджменту
}

\author{
Микола Білокур *А; євген Сидоренко В; Валерій Хребет с; \\ Іван Гомола ${ }^{\mathrm{D}}$; Віктор Гудима ${ }^{\mathrm{F}}$; Сергій Копашинський ${ }^{\mathrm{E}}$ \\ А Центральний науково-дослідний інститут озброєння та військової техніки Збройних Сил України, пр-кт Повітрофлотський 28, м. Київ, 03049, Україна \\ в Центральне бронетанкове управління озброєння Командування Сил логістики Збройних Сил України, вул. Детярівська, 28а, 04112, Україна \\ с Командування Десантно-штурмових військ Збройних Сил України, м. Житомир, Україна \\ о Логістика Оперативного командування “Захід”, м. Рівне, Україна \\ Е Національний університет оборони України імені Івана Черняховського, пр-кт Повітрофлотський 28, м. Київ, 03049, Україна
}

Received: November 04, 2020 | Revised: November 13, 2020 | Accepted: December 31, 2020

DOI: $10.33445 /$ sds.2020.10.6.8

\begin{abstract}
Анотація
Досліджується можливість вдосконалення процесу планування на основі спроможностей з метою мінімізувати потребу в зразках ОВТ та максимізувати набуття спроможностей впродовж їх життєвого циклу. Використовуючи теорію нечітких множин проведено оцінювання альтернативних зразків ОВТ. Розроблено модель нечіткого висновку визначення корисності зразків ОВТ в набутті спроможностей в основу якої покладено нечітку логіку. Здійснено моделювання альтернативних зразків ОВТ щодо витрат на стадіях життєвого циклу “Використання» та «Підтримка» використовуючи сучасне програмне середовище MATLAB. Результати моделювання надали можливість на етапі планування підвищити ефективність управління оборонними ресурсами використовуючи значення корисності зразків ОВТ. Впровадження в оборонний менеджмент розробленої моделі дозволяє в автоматичному режимі без участі експертів визначати зразки ОВТ, враховуючи вартість їх житєєого циклу та наблизити процес планування до євроатлантичних підходів.
\end{abstract}

Ключові слова: зразок озброєння, вдосконалення процедури планування, властивості зразків ОВТ під час його оцінювання, вартість етапів життєвого циклу зразків ОВТ.

\section{Постановка проблеми}

Одним з важливих процесів в набутті й розвиту спроможностей в Збройних Силах України (ЗС України) $є$ процес планування. Від нього залежать результати здійснення процесів програмування, бюджетування й виконання. Вдосконалення процедури планування, в першу чергу, спрямоване на ефективне використання оборонних ресурсів. Враховуючи принципи й стандарти НАТО при здійсненні оборонного планування В 3 С України та впроваджуючи у діяльність Міністерства оборони України (МО України) програмно-проектний менеджмент, існує потреба у вдосконаленні існуючої системи оборонного планування. Удосконалення процесу планування, в рамках методології програмно-проектного менеджменту в МО України, надасть характерних рис, які властиві оборонному плануванню країн-членів НАТО [1].

Для набуття необхідних спроможностей існує завдання щодо вибору шляхів оснащення носіями спроможностей (зразками озброєння та військової техніки (ОВТ)). Процеси оснащення (придбання) зразків ОВТ для військових формувань (закупівля і розробка) здійснюються у відповідності до існуючого нормативноправового забезпечення в рамках заходів оборонного планування. Підтримка таких заходів за допомогою наукового-технічного супроводження не виключає на сучасному

\footnotetext{
* Corresponding author: ад'юнкт науково-організаційного відділу, e-mail: nikolas200578@gmail.com, ORCID: 0000-0002-2954-8497
} 
етапі використання методів експертних оцінок, що несуть в собі певні похибки в суб'єктивних судженнях експертів [2]. Вдосконалення процедури планування в оборонному менеджменті обумовлено необхідністю усунення похибок в існуючому науково-методичному забезпеченні.

\section{Аналіз останніх досліджень та публікацій}

Теоретичною основою статті стали опрацьовані Методичні рекомендації 3 фінансово-економічного обгрунтування вартості повного життєвого циклу спроможностей з урахуванням принципів та стандартів НАТО та наукові публікації фахівців в даній галузі. Зокрема можна виокремити такі праці, як “Проектирование нечетких систем средствами MATLAB", Штовба С.Д.; "Fuzzy identification of system sand its application to modeling and control", Takagi T.,
Sugeno М.; “Принятие решений в расплывчатых условиях", Беллман Р., Заде Л.; "Proposed Methodology to Characterize the Accuracy of Life Cycle Cost Estimates for DoD Programs", E. Ryan, D. Jacques, J. Colombi, C. Schubert. "Investigation in to the Ratio of Operating and Support Costs to Life-Cycle Costs for DoD Weapon Systems", Gary Jones, Erin Ryan, Tony White \& Jonathan Ritschel., а також окремі публікації в навчальній і науковій літературі з цієї проблематики.

\section{Постановка завдання}

За відсутності на теперішній час у замовника під час планування моделі витрат за відповідними стадіями життвого циклу та відповідної бази даних [3] і враховуючи нечіткі статистичні дані за витратами на кожній стадії життєвого циклу, авторами для вирішення наукового завдання запропоновано використання нечіткої логіки, а використання сучасного програмного забезпечення для вирішення таких завдань $є$ зручним засобом [68]. На основі нечіткого логічного виведення будуються системи керування, подання знань, підтримки прийняття рішень, апроксимації, оптимізації, структурної та параметричної ідентифікації, що знаходять широке застосування у військовій справі, економіці та інших галузях [9-11].

Відповідно, авторами статті запропоновано в процесі планування здійснювати обгрунтування шляхів оснащення військових формувань ОВТ, а саме:

кількісно-вартісних показників окремих етапів життєвого циклу вже розроблених зразків ОВТ;

кількісно-вартісних показників окремих етапів життєвого циклу зразків ОВТ, які розробляються(в якості висунення вимог).

Зазначені обґрунтування в процесі планування запропоновано здійснювати за рахунок проведення моделювання 3 обмеженнями щодо рівня ефективності альтернативних зразків ОВТ. Рівень ефективності зразків ОВТ передбачено враховувати в якості коефіцієнта технічного рівня, який попередньо визначений.

вимірювання здійснено 3 допомогою нечіткого висновку, дескриптивна модель якого зображена на рис. 1. На вхід моделі подаються оцінки витрат за критеріями, а виходом $є$ визначення корисності зразка ОВТ. Корисність $€$ мірою забезпечення, яку отримує суб'єкт (споживач) в постачанні матеріальних засобів (зразків ОВТ) та залежить від потреби $[14,15]$. 


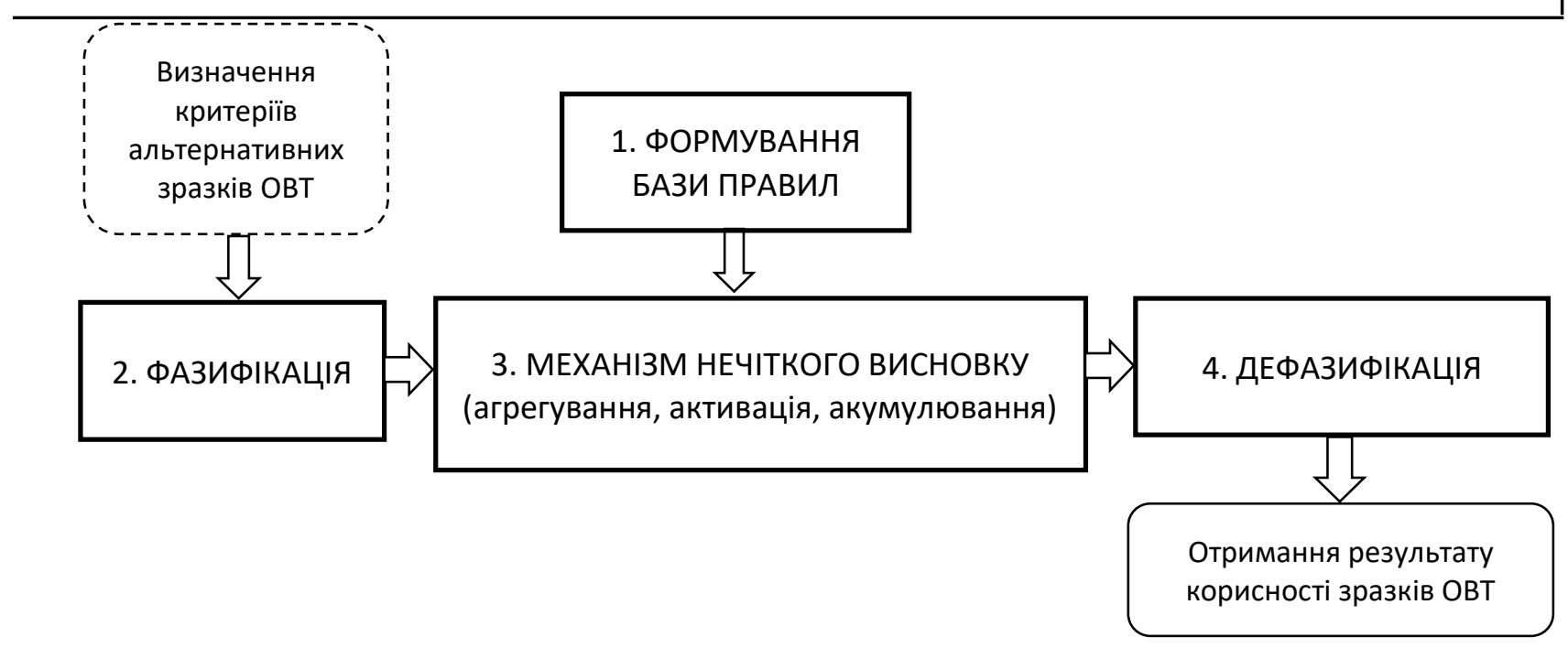

Малюнок 1 - Дескриптивна модель нечіткого висновку визначення корисності зразків ОВТ в набутті спроможностей

В моделі нечіткого висновку між оцінками витрат щодо альтернативних зразків ОВТ, які подаються на вхід моделі та отриманням значень їх корисності використаний апарат логічних операцій за алгоритмом Мамдані:

1. Формування бази продукційних правил (продукцій) відповідно до матриці (табл.1), що наведена в табличній формі розмірністю $(n+1) \cdot N[16]$,

де: $(n+1)$ число стовбців;

$N=\left\{k_{1}, k_{2}, \ldots k_{i}\right\}-$ число строк;

$11,12, \ldots 1 k_{1}$ - номера комбінацій вхідних

\section{Таблиця 1 - Матриця правил}

\begin{tabular}{|c|c|c|c|c|c|}
\hline \multirow{2}{*}{$\begin{array}{c}\text { Номер комбінації } \\
\text { значень }\end{array}$} & \multicolumn{4}{|c|}{ Вхідні змінні } & \multirow{2}{*}{$\frac{\text { Вихідна змінна }}{\text { у }}$} \\
\hline & $\beta_{1}$ & $\beta_{2}$ & $\beta_{\mathrm{i}}$ & $\beta_{n}$ & \\
\hline 11 & $\alpha_{1}^{11}$ & $\alpha_{2}^{11}$ & $\ldots . \alpha_{i}^{11}$. & $\alpha_{n}^{11}$ & \multirow{4}{*}{$\omega_{1}$} \\
\hline 12 & $\alpha_{1}^{12}$ & $\alpha_{2}^{12}$ & $\ldots . \alpha_{i}^{12}$. & $\alpha_{n}^{12}$ & \\
\hline$\ldots$ & & & & & \\
\hline $1 k_{1}$ & $\alpha_{1}^{1 k_{1}}$ & $\alpha_{2}^{1 k_{1}}$ & $\ldots \alpha_{i}^{1 k_{1}} \ldots$ & $\alpha_{n}^{1 k_{1}}$ & \\
\hline$\ldots$ & & & & & \\
\hline$j 1$ & $\alpha_{1}^{j 1}$ & $\alpha_{2}^{j 1}$ & $\ldots . \alpha_{i}^{j 1}$ & $\alpha_{n}^{j 2}$ & \multirow{4}{*}{$\omega_{j}$} \\
\hline$j 2$ & $\alpha_{1}^{j 2}$ & $\alpha_{2}^{j 2}$ & $\ldots \alpha_{i}^{j 2}$ & $\alpha_{n}^{j 1}$ & \\
\hline$\ldots$ & & & & & \\
\hline$j k_{j}$ & $\alpha^{j k_{j}}$ & $\alpha^{j k_{j}}$ & $\ldots \alpha^{j k_{j}}$ & $\alpha^{j k_{j}}$ & \\
\hline$\ldots$ & & & & & \\
\hline$m 1$ & $\alpha_{1}^{m 1}$ & $\alpha_{2}^{m 1}$ & $\ldots \alpha_{i}^{m 1} \ldots$ & $\alpha_{n}^{m 1}$ & \multirow{4}{*}{$\omega_{m}$} \\
\hline$m 2$ & $\alpha_{1}^{m 2}$ & $\alpha_{2}^{m 2}$ & $\ldots \alpha_{i}^{m 2} \ldots$ & $\alpha_{n}^{m 2}$ & \\
\hline$\ldots$ & & & & & \\
\hline$m k$ & $\alpha_{1}^{m k}$ & $\alpha_{2}^{m k}$ & $\ldots . \alpha_{i}^{m k}$ & $\alpha_{n}^{m k}$ & \\
\hline
\end{tabular}

змінних для рішення $\omega_{1}$;

$j 1, j 2, \ldots j k_{1}-$ номера комбінацій вхідних змінних для рішення $\omega_{j}$;

$\left\{\omega_{1}, \omega_{j}, \ldots \omega_{m}\right\}-$ лінгвістичні терми змінної $y$;

$m 1, m 2, \ldots m k_{1}$ - номера комбінацій вхідних змінних для рішення $\omega_{m}$;

$\left\{\alpha_{i}^{1}, \alpha_{i}^{2}, \ldots \alpha_{i}^{j_{i}}\right\}-$ лінгвістичні терми змінних $\beta_{i},(\mathrm{i}=\overline{1, n})$.

Кількість всіх комбінацій $R$, розраховується згідно виразу:

$$
R=\alpha^{\beta}
$$


2. Фазифікація вхідних змінних процедура знаходження значень функції належності нечітких множин (термів) на основі вхідних значень:

$$
a_{i j} \in X_{i}
$$

де $a_{i j}-$ множина значень вхідної змінної, що використовується в якості аргументу функції належності $\mu(x)$,

$X_{i}$ - універсум лінгвістичної змінної $\beta_{i}$.

3. Агрегування - знаходження ступеню істинності умов кожного з правил системи нечіткого виводу використовуючи парні логічні операції кон'юнкції (AND) та диз'юнкції (OR):

$$
\begin{aligned}
\mathrm{T}(\mathrm{A} \wedge \mathrm{B}) & =\min \{\mathrm{T}(\mathrm{A}), \mathrm{T}(\mathrm{B})\}, \mathrm{T}(\mathrm{A} \vee \mathrm{B})= \\
= & \max \{\mathrm{T}(\mathrm{A}), \mathrm{T}(\mathrm{B})\},
\end{aligned}
$$

4. Активація - знаходження ступеню істинності під виводу (всіх значень кожного правила)з визначенням функції належності вихідних лінгвістичних змінних враховуючи вагові коефіцієнти кожного правила:

$$
\mu(\gamma)=\min \left\{c_{i}, \mu(\gamma)\right\},
$$

де: $\mu^{\prime}(y)$ - результат активації;

$\mu(y)$ - функція належності терма, який $€$ значенням деякої вихідної змінної, заданої на універсумі $Y$;

$\mathrm{c}_{i}$ - добуток результатів отриманих висновків на ваговий коефіцієнт правила.

\section{5. Акумулювання - об'єднання} (акумуляція) всіх ступенів істинності виводів та отримання функції належності кожної із вихідних змінних отримавши множину $D$ на універсумі $Y$, функція належності якої визначається згідно виразу:

$$
\mu_{D}(\omega)=\max \left\{\mu_{A}(\omega), \mu_{B}(\omega)\right\}(\forall \omega \in Y),
$$

6. Дефазифікація в системі нечіткого висновку - знаходження звичайних значень для кожної з вихідних лінгвістичних змінних.

Результатом дефазифікації вихідних лінгвістичних змінних $\omega_{j} \in$ кількісне значення, яке отримано найпоширенішим методом дефазифікації, з саме, методом центра ваги:

$$
Z=\frac{\int_{\min }^{\max } \omega \mu(\omega) d \omega}{\int_{\min }^{\max } \mu(\omega) d \omega}
$$

де: $z$ - результат дефазифікації;

$\omega$-вихідна лінгвістична змінна;

$\mu(\omega)$ - функція належності нечіткої множини відповідної вихідної змінної $\omega$ після акумулювання;

min i мax - ліва и права точки інтервалу носія нечіткої множини вихідної змінної $\omega$.

Щоб мінімізувати потребу в зразках ОВТ та максимізувати набуття спроможностей (здійснити їх розвиток) впродовж життєвого циклу спроможності авторами на етапі планування здійснено моделювання використовуючи методи нечіткої логіки та отримано корисність зразків ОВТ [17-19]. Це надало можливість використати такі значення для ефективного управління оборонними ресурсами спрямованих на оснащення військових формувань ОВТ на наступних етапах оборонного менеджменту під час програмування, бюджетування й виконання. Моделювання здійснено на прикладі розвитку спроможності окремої механізованої бригади (Омбр) ЗС України [20], носіями якої визначені наступні зразки ОВТ: БТР 70, БТР 80, БТР ЗДА, БТР 4Е. Відповідно моделі нечіткого висновку (мал. 1) визначені критерії оцінки зразків ОВТ на стадіях життєвого циклу "Використання" та “Підтримка", які наведені в таблиці 2.

Таблиця 2 - Критерії оцінки зразків ОВТ на стадіях життєвого циклу “Використання" та “Підтримка”

\begin{tabular}{|c|l|}
\hline № з/п & \multicolumn{1}{|c|}{ Назва } \\
\hline 1. & Витрати на боєприпаси під час використання зразка \\
\hline 2. & Витрати на енергоносії (ПММ) при використанні \\
\hline 3. & Витрати на матеріальні засоби при зберіганні (короткострокове, тривале) \\
\hline 4. & Витрати на регламентоване технічне обслуговування (РТО) під час зняптя зі зберігання \\
\hline 5. & Придбання витратних матеріалів, запасних інструментів та приладдя (зІП) і \\
\hline
\end{tabular}




\begin{tabular}{|c|l|}
\hline \hline № 3/п & \multicolumn{1}{|c|}{ Назва } \\
\hline & комплектувальних виробів при ешелонуванні \\
\hline 6. & Витрати при технічному обслуговуванні \\
\hline 7. & $\begin{array}{l}\text { Придбання додаткових засобів технічного обслуговування і ремонту (ТОіР), в окремий } \\
\text { підрозділ (вартість яких наближено становить вартість зразка ОВТ) }\end{array}$ \\
\hline 8. & Витрати на ремонт військовими частинами \\
\hline 9. & Витрати на ремонт ремонтно-відновлювальними органами оперативної ланки \\
\hline 10. & Витрати на ремонт підприємствами промисловості \\
\hline
\end{tabular}

Для проектування нечіткого висновку обрано програмне середовище MATLAB використовуючи в ньому пакет FuzzyLogicDesigner.
Дія 1 в моделі нечіткого висновку (мал.1) стосується визначенню множини вхідних і вихідних лінгвістичних змінних для побудови бази правил (табл. 3).

Таблиця 3 - Множини вхідних і вихідних лінгвістичних змінних та їх терми

\begin{tabular}{|c|c|}
\hline $\begin{array}{c}\text { Множина вхідних лінгвістичних } \\
\text { змінних (V) }\end{array}$ & $\begin{array}{c}\text { Терм-множина } \\
\text { вхідної лінгвістичної змінної }\end{array}$ \\
\hline $\begin{array}{l}\text { B }_{1} \text { - витрати на боєприпаси під час } \\
\text { використання зразка }\end{array}$ & $\begin{array}{l}\alpha_{1}-\text { вартість в межах існуючого зразка, "P" } \\
\alpha_{2}-\text { вартість в рази перевищує витрати існуючого зразка, “ } N \text { " }\end{array}$ \\
\hline $\begin{array}{l}\text { b }_{2} \text { - витрати на енергоносії (ПММ) при } \\
\text { використанні }\end{array}$ & $\begin{array}{l}\alpha_{1}-\text { вартість в межах існуючого зразка, "P" } \\
\alpha_{2}-\text { вартість в рази перевищує витрати існуючого зразка, “N" }\end{array}$ \\
\hline $\begin{array}{l}\text { 8 з-витрати на матеріальні засоби } \\
\text { при зберіганні (короткострокове, } \\
\text { тривале) }\end{array}$ & $\begin{array}{l}\alpha_{1}-\text { вартість в межах існуючого зразка, “P” } \\
\alpha_{2}-\text { вартість в рази перевищує витрати існуючого зразка, “ } N \text { " }\end{array}$ \\
\hline $\begin{array}{l}\text { 84- витрати на РТО під час зняття зі } \\
\text { зберігання }\end{array}$ & $\begin{array}{l}\alpha_{1}-\text { вартість в межах існуючого зразка, “P” } \\
\alpha_{2}-\text { вартість в рази перевищує витрати існуючого зразка, “ } N \text { " }\end{array}$ \\
\hline $\begin{array}{l}\text { 8 } 5 \text { - придбання витратних матеріалів, } \\
\text { ЗІП і комплектувальних виробів при } \\
\text { ешелонуванні }\end{array}$ & $\begin{array}{l}\alpha_{1}-\text { вартість в межах існуючого зразка, “P” } \\
\alpha_{2}-\text { вартість в рази перевищує витрати існуючого зразка, “ } N \text { " }\end{array}$ \\
\hline $\begin{array}{l}\text { B } 6 \text { - витрати при технічному } \\
\text { обслуговуванні }\end{array}$ & $\begin{array}{l}\alpha_{1}-\text { вартість в межах існуючого зразка, "P" } \\
\alpha_{2}-\text { вартість в рази перевищує витрати існуючого зразка, “N" }\end{array}$ \\
\hline $\begin{array}{l}\text { 8 7- придбання додаткових засобів ( } n \text { ) } \\
\text { ТОіР, в окремий підрозділ (вартість } \\
\text { яких наближено становить вартість } \\
\text { зразка ОВТ) }\end{array}$ & $\begin{array}{l}\alpha_{1}-\text { не потребує, «P» } \\
\alpha_{2}-\text { потребує необхідну кількість } n-\text { их засобів, “ } N \text { ” }\end{array}$ \\
\hline $\begin{array}{l}\text { 8 }{ }_{8}-\text { витрати на ремонт військовими } \\
\text { частинами }\end{array}$ & $\begin{array}{l}\alpha_{1}-\text { вартість в межах існуючого зразка, “P” } \\
\alpha_{2}-\text { вартість в рази перевищує витрати існуючого зразка, “ } N \text { ” }\end{array}$ \\
\hline $\begin{array}{l}\text { 8 }_{9} \text {-витрати на ремонт ремонтно- } \\
\text { відновлювальними органами } \\
\text { оперативної ланки }\end{array}$ & $\begin{array}{l}\alpha_{1}-\text { вартість в межах існуючого зразка, “P” } \\
\alpha_{2}-\text { вартість в рази перевищує витрати існуючого зразка, “ } N \text { ” }\end{array}$ \\
\hline $\begin{array}{l}\text { B }_{10} \text {-витрати на ремонт } \\
\text { підприємствами промисловості }\end{array}$ & $\begin{array}{l}\alpha_{1}-\text { вартість в межах існуючого зразка, “P” } \\
\alpha_{2}-\text { вартість в рази перевищує витрати існуючого зразка, “ } N \text { " }\end{array}$ \\
\hline Вихідна лінгвістична змінна (W) & Терм-множина вихідної лінгвістичної змінної \\
\hline Корисність & $\begin{array}{l}\omega_{1}-\text { max оснащення носіями спроможності “P” } \\
\omega_{2}-\text { minocнащення носіями спроможності “ } N \text { " }\end{array}$ \\
\hline
\end{tabular}

Для побудови множини $V, W$ (табл. 3) авторами були визначені базові терм множини вхідних " $\beta \in V$ " та вихідних лінгвістичних змінних “ $\omega \in W$ " та скориставшись значеннями шкали Харрінгтона, Грина, Лайкерта та інших [21-23] визначені їх терм-множини. Оскільки, із альтернативних зразків ОВТ доцільно віддавити перевагу зразку 3 найвищим значенням корисності 3 існуючих значень шкал (Negative Big (NB), Negative Middle (NM), Negative Small (NS), Zero Negative (ZN), Zero 
(Z), Zero Positive (ZP), Positive Small (PS), Positive Middle (PM), Positive Big (PB)), було обрано лише два терма вхідної та вихідної лінгвістичної змінної Positive (P) ma Negative $(N)$.

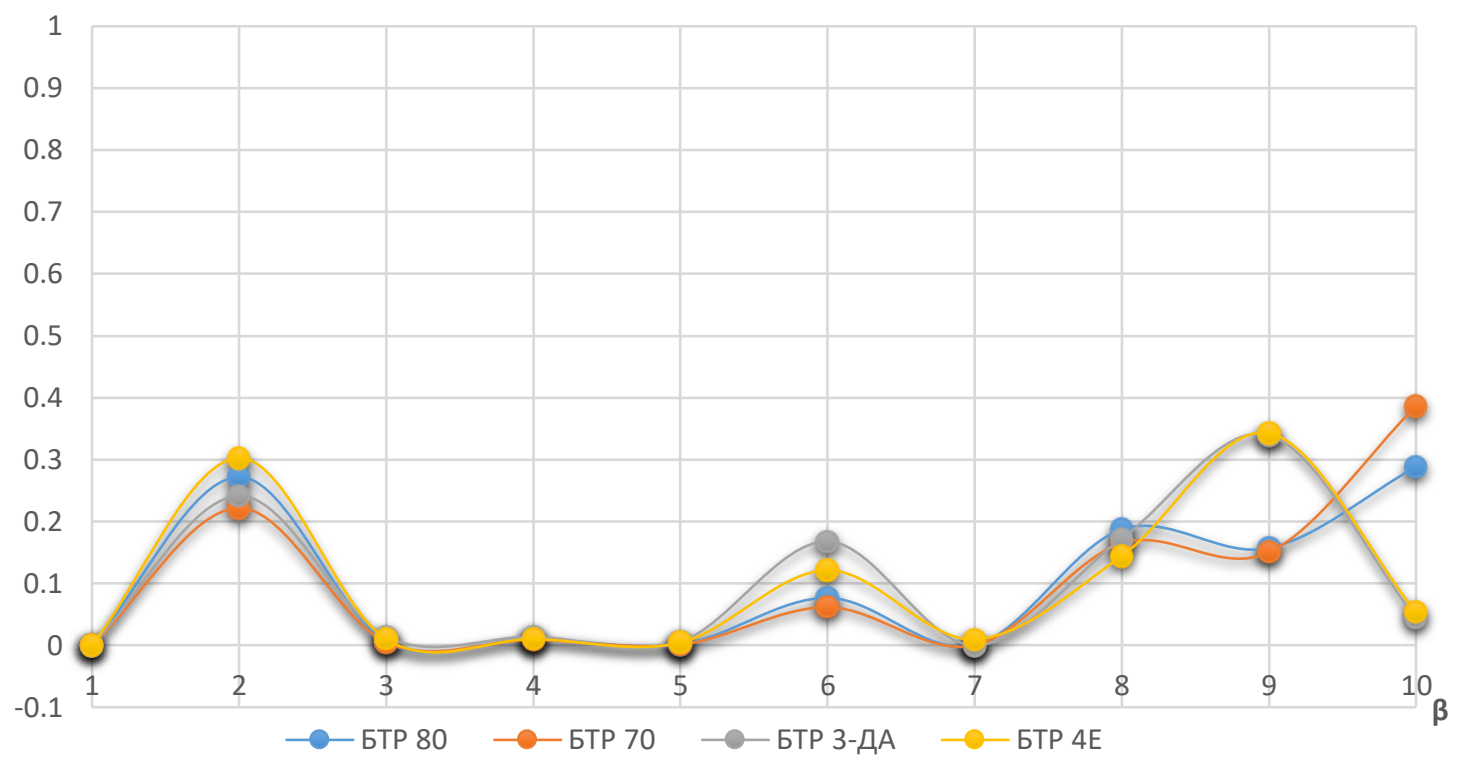

Малюнок 3 - Діаграма оцінювання витрат альтернативних зразків ОВТ відповідно вхідних лінгвістичних змінних

Розрахувавши кількість правил за виразом

(1) отримано: $\mathrm{R}=\alpha^{\beta}=2^{10}=1024$.

Використовуючи програмне забезпечення база правил відповідає наступній формі[24]:

RULE 1 (Правило 1): IF (ЯКЩО) Condition 1 («Умова 1») THEN (ТОДІ) Conciusion 1 (Висновок 1) - F1

RULE 2 (Правило 2): IF (ЯКЩО) Condition 2 («Умова 2») THEN (ТОДІ) Conciusion 2 (Висновок 2) - F2

RULEn (Правило n): IF (ЯКЩО) Conditionn («Умова $\mathrm{n} »)$ THEN (ТОДІ) Conciusionn (Висновок n) $-F n$

де: $F$ - ваговий коефіцієнт відповідних правил в інтервалі $[0,1]$.

Ваговий коефіцієнт $F$ в правилах не застосований (правила мають однакову вагу). Вхідні лінгвістичні змінні, мають два терма відповідно до множини V:

$P$, якщо їх значення $\leq$ витратам однотипного існуючого зразка ОВТ, який перебуває на озброєнні;
$N$, якщо їх значення $\epsilon$ більшими ніж витрати зразка ОВТ, який перебуває на озброєнні.

1024 правила утворені перебором умов правил використовуючи вхідні терми $(P, N)$, а висновки в кожному правилі відповідають вихідній лінгвістичній змінній, яка теж має два терма $(P, N)$. Якщо алгебраїчна сума умов $n$-го правила перевищувала значення більше 0,5 - вихідна лінгвістична змінна приймала значення терму Nта навпаки неперевищуючі значення алгебраїчної суми 0,5 - значення терму $P$.

Отримавши від споживача зразків ОВТ всі можливі дані щодо витрат під час їх використання за призначенням побудовано діаграму витрат (рис. 3),яку було використано для здійснення підсумування умов. Для цього здійснено унормування значень (табл. 4), які відображають ваговий коефіцієнт критеріїв оцінки зразків ОВТ на стадіях життєвого циклу “Використання" та "Підтримка".

Таблиця 4 - Вага критеріїв щодо етапів життєвого циклу “Використання” та “Підтримка”

\begin{tabular}{|c|c|c|c|c|c|c|c|c|c|c|}
\hline № критерію & 1 & 2 & 3 & 4 & 5 & 6 & 7 & 8 & 9 & 10 \\
\hline $\begin{array}{c}\text { Ваговий } \\
\text { коефіцієнт }\end{array}$ & 0,0004 & 0,3580 & 0,0078 & 0,0095 & 0,0031 & 0,0961 & 0,0029 & 0,1430 & 0,2285 & 0,1508 \\
\hline
\end{tabular}


Дія 2 в моделі нечіткого висновку, як етап введення нечіткості (фазифікація) $€$ процедурою знаходження значень функції належності нечітких множин на основі наявних даних отриманих споживачами зразків ОВТ на стадіях життєвого циклу "Використання" та “Підтримка".

Визначення лінгвістичних змінних, а також

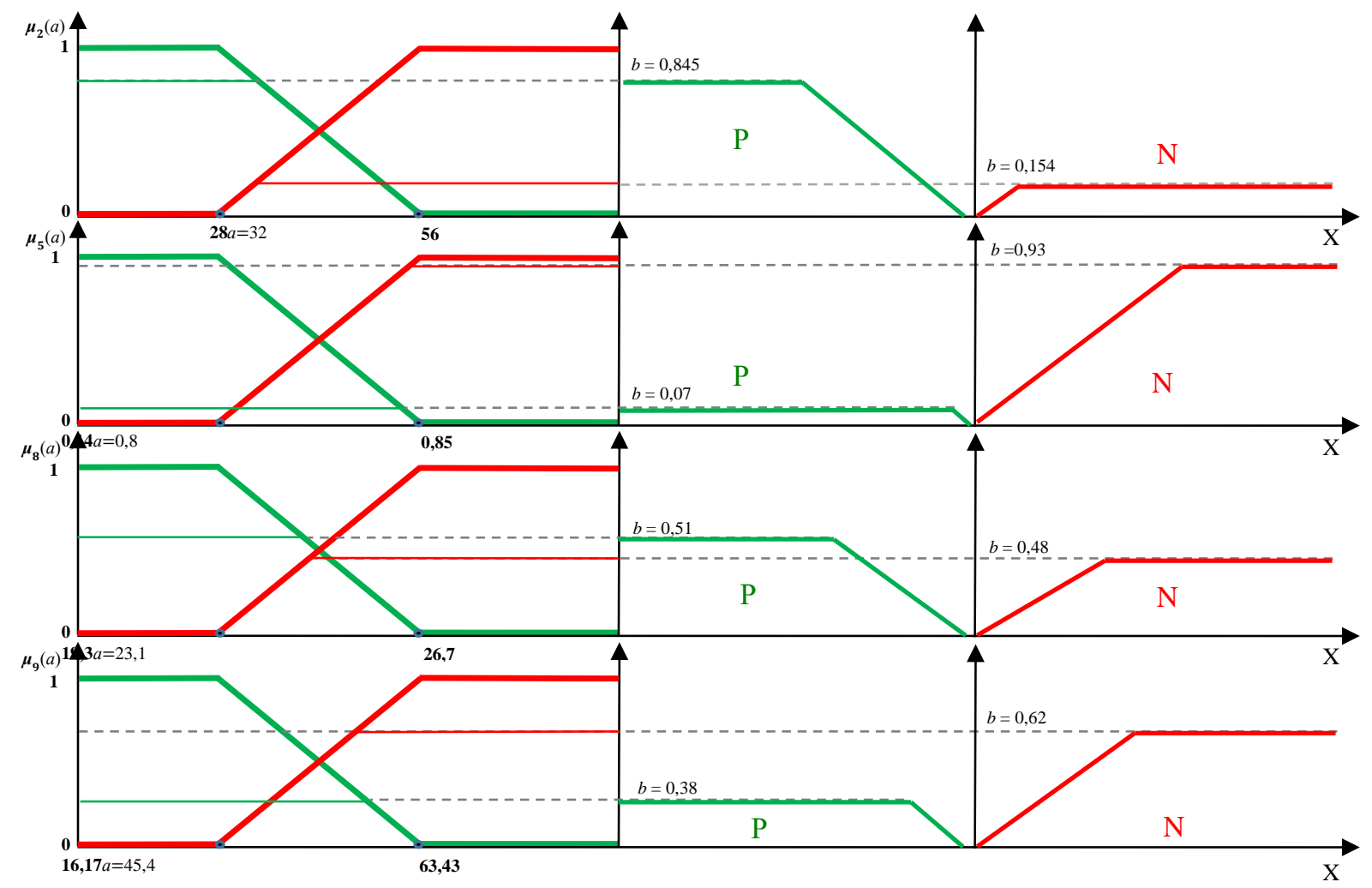

необхідних для формалізації функцій належності для наочності вибірково зображено на прикладі БТР ЗДА (мал.2). Оцінки за відповідними лінгвістичними змінними $b_{2}, b_{5}, b_{8}, b_{9}$ визначають межі нечіткої множини, у вигляді трапецієвидного нечіткого інтервалу.

Малюнок 2 - Функції належності для БТР 3-ДА на етапі фазифікації агрегування й активації

Значення $\mu_{i}(a)$ для БТР ЗДА отримано при вибірці 35 одиниць аналізуючи їх використання за призначенням під час проведення навчань, відновлення боєздатності та інших заходів на протязі двох років. Тому, здійснено приведення моторесурсу до витрат, які визначені на мирний час у керівних документах, а розрахунки приведені до витрат підрозділу штат якого відповідає чисельності механізованого батальйону та терміну використання 20 років. Термін використання зумовлений досвідом використання зразків відповідно належності їх до роду військ, а чисельність з огляду на наявність прямих та спряжених витрат, обчислення яких доцільно було здійснити 3 приведенням до чисельності батальйону [25, 
Відповідно решти альтернативних зразків 196 одиниць. Внормовані результати область значень $V$ розрахована з вибіркою в приведені в таблиці 5.

Таблиця 5 - Внормовані та узагальнені значення оцінок вхідних лінгвістичних змінних

\begin{tabular}{|c|c|c|c|c|c|c|c|c|}
\hline \multirow{2}{*}{$\begin{array}{c}\text { Вхідні } \\
\text { лінгвістичні } \\
\text { змінні (V) }\end{array}$} & \multicolumn{4}{|c|}{$\begin{array}{c}\text { Внормовані значення оцінок вхідних } \\
\text { лінгвістичних змінних }\end{array}$} & \multicolumn{4}{|c|}{$\begin{array}{c}\text { Узагальнені значення оцінок що враховують } \\
\text { ваговий коефіцієнт критерію }\end{array}$} \\
\hline & БТР 70 & БТР 80 & БТР - ЗДА & БТР - 4E & БТР 70 & БТР 80 & БТР - ЗДА & БTP - 4E \\
\hline $1\left(\beta_{1}\right)$ & 0,072583 & 0,072583 & 0,427417 & 0,427417 & 0,00003 & 0,00003 & 0,00017 & 0,00017 \\
\hline $2\left(\beta_{2}\right)$ & 0,193392 & 0,196157 & & & & & & 857 \\
\hline $3\left(\alpha_{3}\right)$ & 0,125995 & 0,125995 & & & & & & \\
\hline $4\left(\beta_{4}\right)$ & 0,18869 & 0,18869 & 0,31131 & & 5755 & 0, & & \\
\hline $5\left(\beta_{5}\right)$ & 0,072165 & 0,07732 & 0,412371 & 0,4 & 0,02584 & 0,02768 & 763 & 586 \\
\hline $6\left(\beta_{6}\right)$ & 0,129933 & 0,129933 & 0,370067 & 0,370067 & 652 & 0,04652 & 248 & 0,13248 \\
\hline $7\left(\alpha_{7}\right)$ & 0 & 0 & 0 & 1 & 0,00000 & 0,00000 & 0,00000 & 0,35800 \\
\hline $8\left(\beta_{8}\right)$ & 0,213762 & 0,234105 & 0,255961 & 0,29617 & 0,07653 & 0,08381 & 0,09163 & 0,10603 \\
\hline $9\left(\beta_{9}\right)$ & 0,112092 & 0,133314 & 0,314913 & 0,43968 & 0,04013 & 0,04773 & 0,11274 & 0,15741 \\
\hline $10\left(\beta_{10}\right)$ & 0,311975 & 0,519958 & 0,063025 & 0,105042 & 0,11169 & 0,18614 & 0,02256 & 0,03761 \\
\hline
\end{tabular}

Дія 3 в моделі нечіткого висновку $\epsilon$ апроксимацією залежності “вхід-вихід” на основі лінгвістичних висловлювань, що сформовані базою правил і логічними операціями над нечіткими множинами:

агрегування - знаходження ступеню істинності умов кожного правила 3 використанням операції логічної кон'юнкції $T\left(A^{\wedge} B\right)=T(A) \cdot T(B)$. Результати наведено В таблиці 6;

активації - шляхом знаходження ступеню істинності висновків $B=\left\{b_{1}, b_{2}, \ldots b_{n}\right\}$ кожного правила (мал. 2);

акумулювання - об'єднання функцій належності висновків, які утворюють нову множину $D$ на універсумі $Y$ (мал. 4).

\section{Таблиця 6 - Значення функцій належності}

\begin{tabular}{|c|c|c|c|c|c|}
\hline \multirow{2}{*}{$\begin{array}{c}\text { Вхідні лінгвістичні } \\
\text { змінні }\end{array}$} & \multirow{2}{*}{ Терми } & \multicolumn{4}{|c|}{ Значення функції належності } \\
\cline { 2 - 6 }$\beta_{1,3,4,6}$ & $P$ & БТР 70 & БТР 80 & БТР - 3ДА & БТР - 4Е \\
\hline \multirow{2}{*}{$\beta_{2}$} & $N$ & 1 & 1 & 0 & 0 \\
\hline \multirow{2}{*}{$\beta_{5}$} & $P$ & 1 & 0 & 1 & 1 \\
\hline \multirow{2}{*}{$\beta_{7}$} & $N$ & 0 & 0,98572 & 0,84511 & 0 \\
\hline \multirow{2}{*}{$\beta_{8}$} & $N$ & 1 & 0,01428 & 0,15489 & 1 \\
\hline \multirow{2}{*}{$\beta_{9}$} & $P$ & 0 & 0,98596 & 0,07045 & 0 \\
\hline \multirow{2}{*}{$\beta_{10}$} & $P$ & 0 & 0,01404 & 0,92955 & 1 \\
\hline & $N$ & 1 & 0 & 1 & 0 \\
\hline & $P$ & 0 & 0,75322 & 0,48814 & 0 \\
\hline & $P$ & 1 & 0,24678 & 0,51186 & 1 \\
\hline & $N$ & 0 & 0,93520 & 0,38088 & 0 \\
\hline & & 0,45513 & 0,06480 & 0,61912 & 1 \\
\hline
\end{tabular}




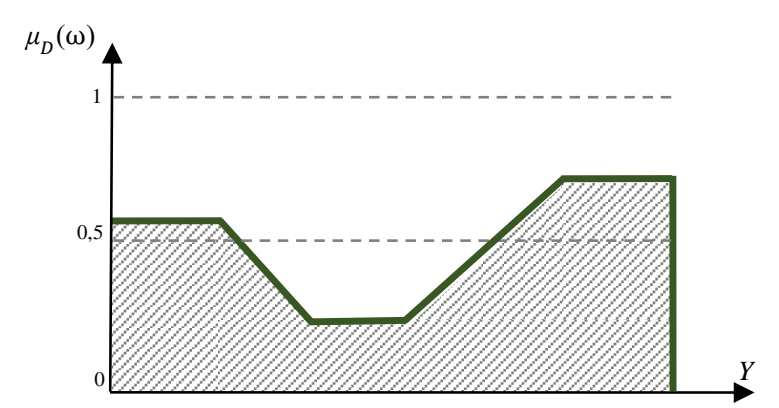

Малюнок 4 - Акумуляція виводу для вихідної лінгвістичної змінної «Корисність»

Оскільки нечітка множина не обмежує дослідника у виборі функції належності авторами при її побудові було обрано не лише найпростішу кусочно-лінійну функцію належності (трапецевидну), в якій ядро $\{b, c\}$ нечіткої множини $\mathrm{A}=\left\{\mathrm{x} \in \mathrm{X} \mid \mu_{\mathrm{A}}(\mathrm{x})=1\right\}$ (мал. 5 a), прямує до нуля в точці «b», що відповідає терму $P$, та до безкінечності (мал. 5 в), на границі нечіткої множини в точці “c" терму $N$,що в свою чергу характеризує нечітку множину безперервним характером. Тому, поряд було здійснено моделювання результати, яких суттєво не відрізняються та не вплинули на значення корисності дослідних зразків ОВТ, але спрощують процес моделювання в програмному середовищі та відрізняються швидкістю операцій під час обчислення. Функцію обрано саме таку, яка має закон розподілення нечіткої множини 3 допомогою двох функцій Гауса, а саме, взявши Z-образну функцію (мал. 5 б), в якій параметри визначають форму кривої належності зліва від модального значення, та S-образну функцію (мал. 5 г), в якій параметри визначають форму кривої праворуч від модального значення, що задаються виразом:

$$
\begin{aligned}
& f_{z}(x ; a, b)=\left\{\begin{array}{ll}
1, & x<a \\
\frac{1}{2}+\frac{1}{2} \cos \left(\frac{x-a}{b-a} \pi\right), & a \leq x \leq b \\
0, & x>b
\end{array}\right\}, \\
& f_{s}(x ; a, b)=\left\{\begin{array}{ll}
0, & x<a \\
\frac{1}{2}+\frac{1}{2} \cos \left(\frac{x-b}{b-a} \pi\right), & a \leq x \leq b \\
1, & x>b
\end{array}\right\},
\end{aligned}
$$

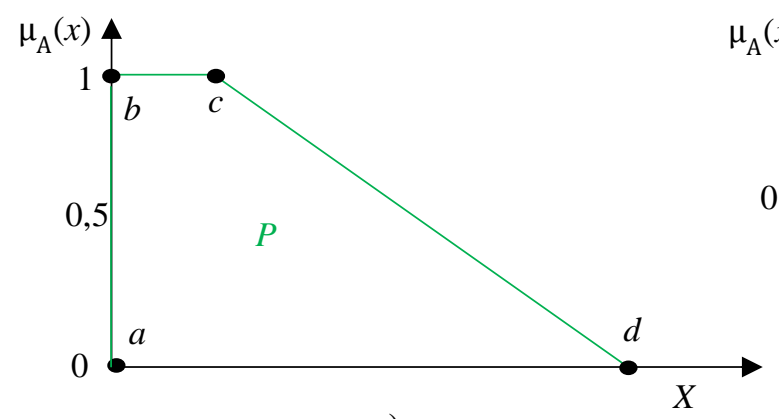

a)

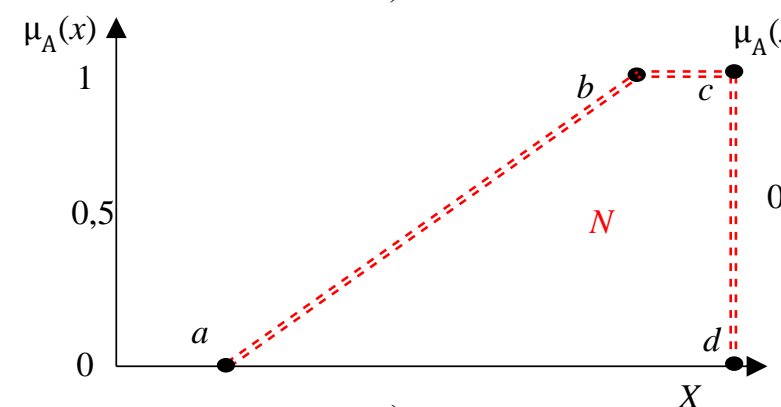

в)

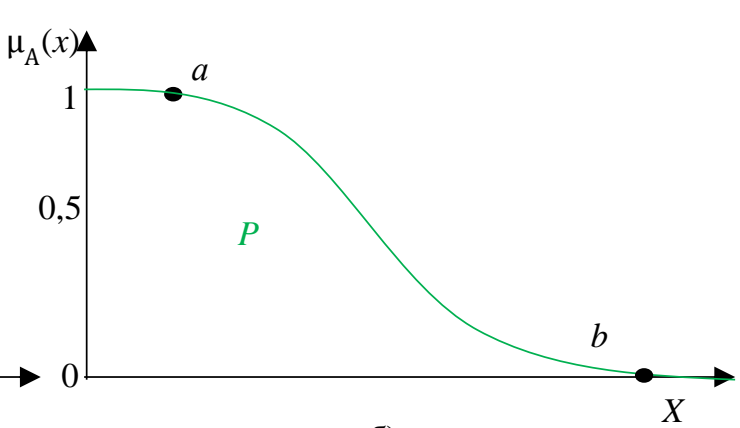

б)

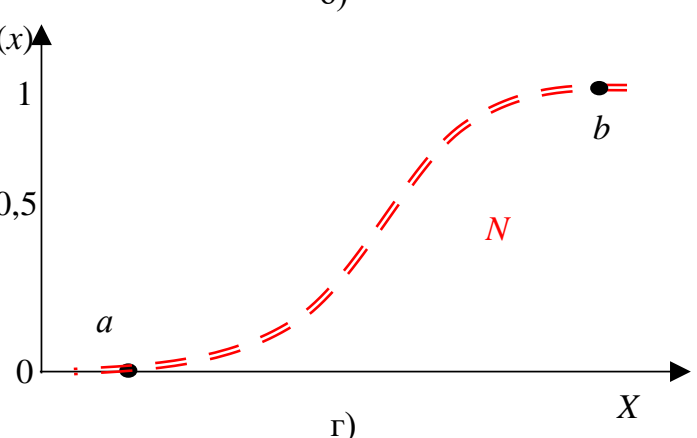

г)

Малюнок 5 - Графіки функцій належності:

а), в) - трапецевидна; б) - Z-образна, г) S-образна

Використовуючи інтерфейс пакету зняття чисельних значень, як дія 4 (процедура FuzzyLogicDesignerна мал. 6 відображено дефазифікації) в моделі нечіткого висновку 
оцінок корисності зразків ОВТ в набутті отримані методом центра ваги наведені в відповідних спроможностей, а результати, які таблиці 7.

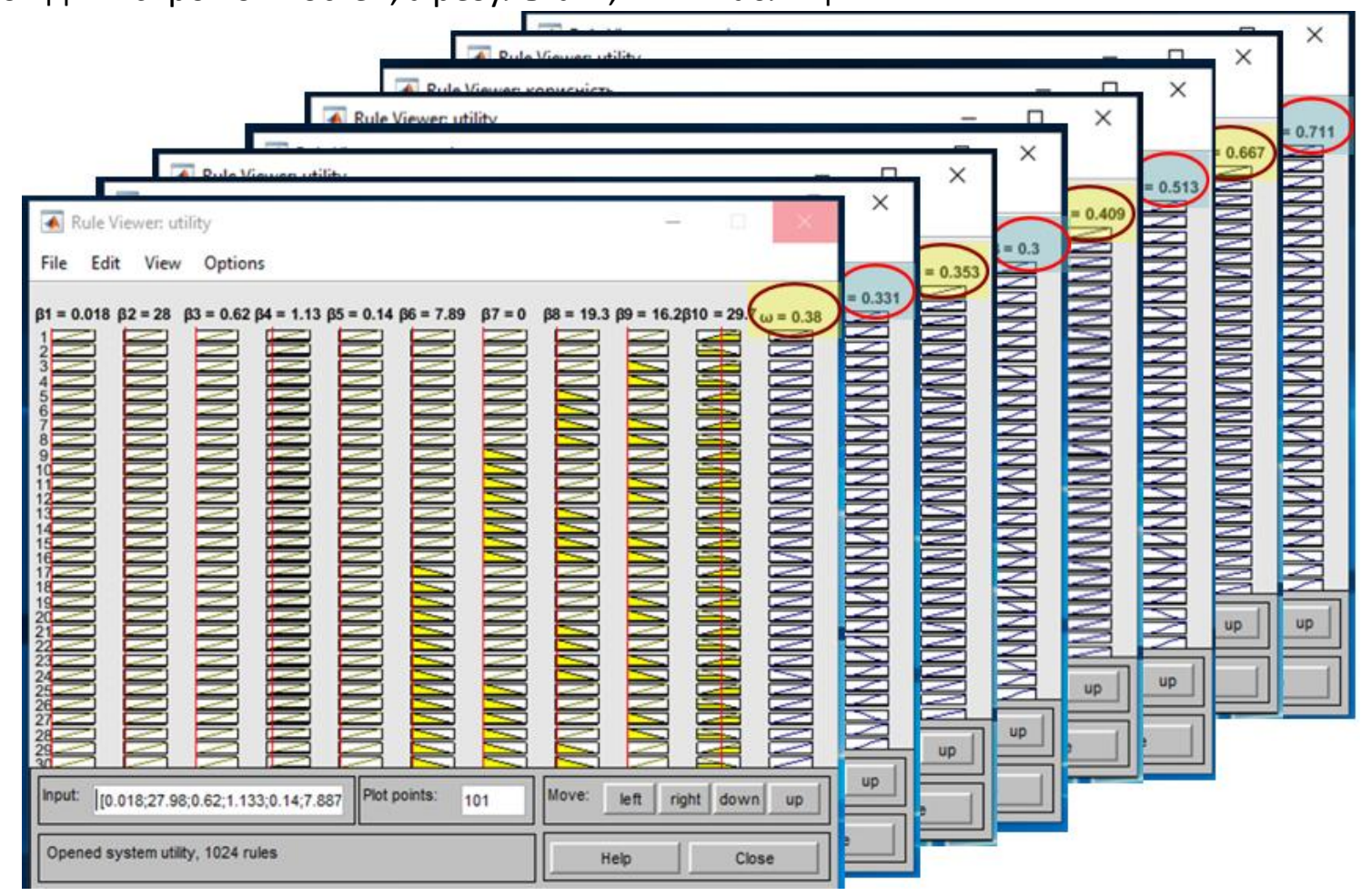

Малюнок 6 - Отримані значення досліджуваних зразків ОВТ після завершення дефазифікації

Таблиця 7 - Оцінки корисності альтернативних зразків ОВТ

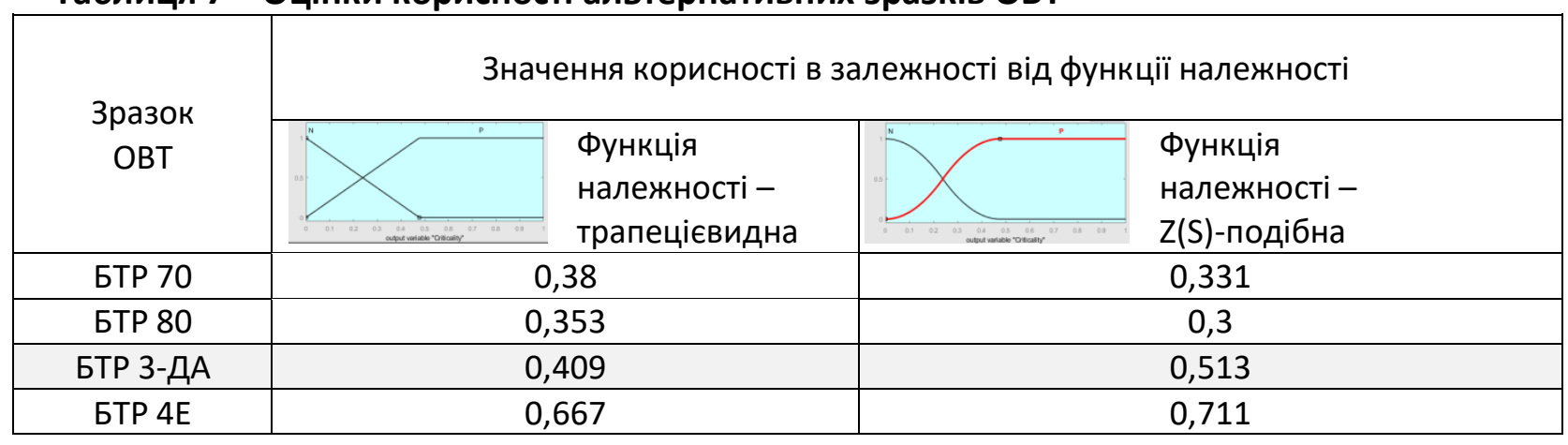

\section{Висновки}

Врахування вартості етапів життєвого циклу зразків ОВТ, які були досліджені за рахунок отриманих значень корисності надає можливість розглядати зразки ОВТ, які найбільш доцільно обрати для оснащення військових формувань та набуття (розвитку)ними максимуму спроможностей. В дослідженні існували обмеження, що стосувалися діючих оперативно-технічних вимог до бронетранспортерів 3 колісною формулою 8х8 для потреб Збройних Сил
України (вимоги до бойового модуля) та визначення значень коефіцієнтів їх технічного рівня [27]. Використовуючи існуючі результати проведених досліджень в цьому напрямі БТР-ЗДА лишається єдиним зразком серед досліджуваних, який має перевагу в корисності та відповідає технічним вимогамна відміну від БТР 70, БТР 80, які їм не відповідають та БТР 4Е, який не має переваги в корисності.

Планування на основі спроможностей 
використовуючи запропоновану модель надає можливість підвищити рівень воєнної безпеки держави за рахунок збільшення міри забезпечення споживача в постачанні зразків OBT, яка залежить від потреби. Підвищити рівень науково-технічного супроводження оборонного менеджменту на етапі планування, який здійснює замовник ОВТ за рахунок вдосконалення науковометодичного забезпечення.

Застосування розробленої моделі під час впровадження методології програмнопроектного менеджменту в систему планування та управління оборонними ресурсами на сучасному етапі надає можливість:

поєднати іï 3 інтелектуальною мережецентричною трансдисциплінарною інформаційно-аналітичною системою 3 сервіс-орієнтованою архітектурою, яка створюється в інтересах замовника ОВТ;

в автоматичному режимі без участі експертів визначати зразки ОВТ із множини альтернативних врахувавши вартість стадій життєвого циклу та підвищити ефективність управління оборонними ресурсами;

обробляти інформаційні ресурси Big Data щодо всіх стадій життєвого циклу парків ОВТ окремих родів та видів 3С України використовуючи математичний апарат, який здатний до обробки нечітких даних;

здійснити перехід від управління даними на стадіях життєвого циклу ОВТ до управління знаннями;

наблизити Україну до євроатлантичних підходів у здійсненні планування.

\section{Список використаних джерел}

1. Чепков І.Б. Порівняльний аналіз систем оборонного планування в США та Україні / І.Б Чепков, В.В. Сотник, І.В.Борохвостов, М.В. Бондарчук, М.О. Білокур // Озброєння та військова техніка. - 2019. - № 3 (23). - С.9 18. DOI: 10.34169/2414-0651.2019.3(23).3-15.

2. Борохвостов І. В. Існуючі зв'язки та протиріччя науково-методичного забезпечення оборонного планування та шляхів оснащення озброєнням військових формувань // І.В.Борохвостов, М.О.Білокур / Збірник наук. праць / ЦНДІ ОВТ ЗС України 2019. - Вип. 1 (72). - С.5- 18.

3. Методичні рекомендації 3 фінансовоекономічного обгрунтування вартості повного життєвого циклу спроможностей $з$ урахуванням принципів та стандартів НАТО. Затверджені МО України 02.06.2020.

4. Gary Jones, Erin Ryan, Tony White \& Jonathan Ritschel. Investigation into the Ratio of Operating and Support Costs to Life-Cycle Costs for DoD Weapon Systems. Defense ARJ. 2014, № 1 (21). Pp. 442-464.

5. Ryan E., Jacques D., Colombi J., Schubert C. A Proposed Methodology to Characterize the Accuracy of Life Cycle Cost Estimates for DoD Programs. Procedia Computer Science 2012 №8 Pp. 361-369. DOI: 10.1016/j.procs.2012. 01.073.
6. Штовба С. Д. Проектирование нечетких систем средствами MATLAB. - М.: Горячая линия - Телеком, 2007. - 288 с.

7. Takagi T., Sugeno M. Fuzzy identification of systems and its application to modeling and control // IEEE Transactions on Systems, Man and Cybernetics. Vol. 15. No 1. 1985. - P. 116132.

8. Беллман Р., Заде Л. Принятие решений в расплывчатых условиях // Вопросы анализа и процедуры принятия решений: Сб. переводов / Под ред. И.Ф. Шахнова. - М.: Мир, 1976. - С. 172-215.

9. Борисов А.Н. Принятиерешений на основе нечетких моделей. Примеры моделей / А.Н. Борисов, О.А. Крумберг, И.П. Федоров. Рига: Зинатне, 1990. - 184 с.

10. Асаи К. Прикладные нечеткие системы [пер. с японского] / Под ред. Т. Тэрано, К. Асаи, М.Сугэно. - М.: Мир, 1993. - 368 с.

11. Sugeno M. Industrial applications of fuzzy control. Elsevier Science Pub. Co., 1985. 269 p.

12. Білокур М. О. Вибір властивостей ОВТ під час моделювання вартості стадій життєвого циклу. 3б. наук. пр. Київ: ЦНДІ ОВТ ЗС України. 2019. Вип. 4 (75). С. $112-118$.

13. Білокур М. О. Функціональне відображення значень ваг в штучній нейронній мережі визначених властивостей при оцінюванні 
альтернативних зразків озброєння // Озброєння та військова техніка. - 2020. - № 2 (26). - C. 20 - 31 DOI: 10.34169/24140651.2020.2(26).20-31.

14. Блауг М. Экономическая мысль в ретроспективе / М. Блауг. - Москва : «Дело Лтд, »-1994. - 720 с.

15. Винер Дж. Концепция полезности в теории ценности и ее критики // Вехи экономической мысли. Теория потребительского поведения и спроса. Т. 1. Под ред. В. М. Гальперина. СПб.: Экономическая школа, 2000.

16. Ротштейн А. П. Интелектуальные технологии: нечёткие множества, генетические алгоритмы, нейронные сети. Винница: «УНІВЕРСУМ-Вінниця»,1999. 320 с.

17. Аверкин А. Н., Батыршин И. 3. и др. Нечеткие множества в моделях управления и искусственного интеллекта / Под. ред. Д.А. Поспелова. - М.: Наука, 1986. - 312 с.

18. Bellman R.E., Zadeh L.A. Decision-making in fuzzy environment // Management Science. Vol.17. No.4. 1970. - Р. 141-164.

19. Мелихов А. Н., Бернштейн Л. С., Коровин С. Я. Ситуационные советующие системы с нечёткой логикой. - М.: Наука, 1990. - 440 с.

20. Рекомендації з оборонного планування на основі спроможностей в Міністерстві оборони України та Збройних Силах України. [Електронний ресурс]. - Режим доступу: https://www.mil.gov.ua/content/other/ Recommendationson_CBP_120617.pdf.

21. Harrington, E.C. Thedesirable function //
Industrial Quality Control. - 1965. -Vol. 21. No. 10. - pp. 494-498.

22. Самохвалов Ю. Я. Оцінка ефективності наукових і науково-технічних проектів на основі узагальненої функції Харрінгтона / Ю. Я. Самохвалов, О. И. Бурба // Системи управління, навігації та зв'язку. Збірник наукових праць. - Полтава: ПНТУ, 2018. - Т. 4 (50). - C. 77-85. DOI: 10.26906/SUNZ. 2018.4.077.

23. Саати Т. Принятие решений. Метод анализа иерархий. - М.: Радио и связь, 1993. - 278 с.

24. Леоненков А. В. Нечеткое моделирование в среде MATLAB и fUzZYTECH. - СПб.: БХВ Петербург, 2005. - 736 с.

25. Нор П.І. Деякі особливості оборонного планування розвитку озброєння та військової техніки Збройних Сил України на основі спроможностей. // П.І.Нор, М.О.Білокур, К.В. Мегей / Збірник наук. праць / ЦНДІ ОВТ ЗС України 2019. - Вип. 3(74). - С.159- 169 .

26. Марютин М. И. Экономика производства, эксплуатации и ремонта вооружения и техники. / М.И. Марютин, С.Ю. Барков, Б.П. Долгополов. - Москва: Военная академия бронетанковых войск им. Малиновского Р.Я, 1989. - 188 с.

27. Нор П. І. Методика оцінки технічного рівня зразків озброєння та військової техніки / П. І. Нор, П. В. Щипанський, С. Ю. Гогонянц // Системи озброєння і військова техніка. 2014. - № 3. - С. $49-54$.

\title{
Выбор образца вооружения на основе нечёткой логики в мероприятиях оборонного менеджмента
}

\section{Николай Белокур * А; Евгений Сидоренко ${ }^{\text {; }}$ Валерий Хребет ; Иван Гомола ${ }^{\mathrm{D}}$; Виктор Гудыма Е; Сергей Копашинський ${ }^{\mathrm{C}}$}

*Corresponding author: адъюнкт научно-исследовательского отдела, e-mail: nikolas200578@gmail.com, ORCID: 0000-0002-2954-8497 А Центральный научно-исследовательский институт вооружения и военной техники ВС Украины, пр-кт Воздухофлотский, 28, г. Киев, 03049, Украина

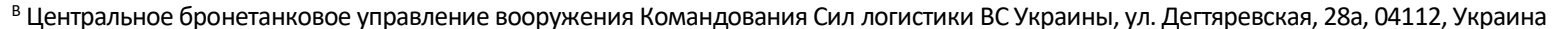
с Командование Десантно-штурмовых войск Вооруженных Сил Украины, г. Житомир, Украина р Логистика Оперативного командования «Запад», г. Ровно, Украина

ЕНациональный университет обороны Украины, пр-кт Воздухофлотский, 28, г. Киев, 03049, Украина

\begin{abstract}
Аннотация
Исследуется возможность совершенствования процесса планирования на основе возможностей с целью минимизировать потребность в образцах ВВТ и максимизировать
\end{abstract}


приобретения способностей в течение их жизненного цикла. Используя теорию нечетких множеств проведена оценка альтернативных образцов ВВТ. Разработана модель нечеткого вывода определения полезности образцов ВВТ в приобретении возможностей, в основу которой положено нечеткую логику. Осуществлено моделирование альтернативных образцов ВВТ по расходам на стадиях жизненного цикла “Использование” и "Поддержка", используя современное программное среду MATLAB. Результаты моделирования предоставили возможность на этапе планирования повысить эффективность управления оборонными ресурсами используя значение полезности образцов ВВТ. Внедрение в оборонительный менеджмент разработанной модели позволяет в автоматическом режиме без участия экспертов определять образцы ВВТ, учитывая стоимость их жизненного цикла $и$ приблизить процесс планирования к евроатлантическим подходам.

Ключевые слова: образец вооружения, совершенствования процедуры планирования, свойства образцов ВВТ при его оценке, стоимость этапов жизненного цикла образцов ВВТ.

\title{
Choice of weapon sample based on fuzzy logic in defense management measures
}

\author{
Mykola Bilokur *A; EvgenSidorenko ${ }^{\mathrm{B}}$; Valeriy Khrebet ${ }^{\mathrm{C}}$; \\ Ivan Gomola ${ }^{D}$; Viktor Hudyma ${ }^{\text {; }}$ Sergii Kopashynski ${ }^{\mathrm{E}}$ \\ *Corresponding author: PhD student, e-mail: nikolas200578@gmail.com, ORCID: 0000-0002-2954-8497 \\ A Central Research Institute of Armaments and Military Equipment Armed Forces of Ukraine, 28, Vozduhoflotsky, ave, Kyiv, 03049, Ukraine \\ ${ }^{B}$ National Defense University of Ukraine named after Ivan Chernyakhovskyi, 28, Vozduhoflotsky, ave, Kyiv, 03049, Ukraine \\ ${ }^{\mathrm{C}}$ Command of the Air Assault Forces of the Armed Forces of Ukraine, Zhytomyr, Ukraine \\ DLogistics of Operational Command "West", Rivne, Ukraine \\ E National Defense University of Ukraine named after Ivan Chernyakhovskyi, 28, Vozduhoflotsky, ave, Kyiv, 03049, Ukraine
}

\begin{abstract}
The possibility of improving the capability-based planning process is being investigated in order to minimize the need for weapons and military equipment and to maximize the acquisition of capabilities during their life cycle. Using the theory of fuzzy sets, the assessment of alternative samples of weapons and military equipment is carried out. A fuzzy inference model for determining the usefulness of weapons and military equipment in acquiring opportunities has been developed, based on fuzzy logic. The modeling of alternative models of weapons and military equipment was carried out in terms of costs at the stages of the life cycle "Use" and "Support" using the modern software environment MATLAB. The simulation results provided an opportunity at the planning stage to improve the efficiency of defense resource management using the value of the usefulness of weapons and military equipment. The introduction of the developed model into defense management makes it possible to automatically determine weapons and military equipment without the participation of experts, taking into account the cost of their life cycle and to bring the planning process closer to Euro-Atlantic approaches.
\end{abstract}

Keywords: weapon model, improvement of the planning procedure, properties of weapons and military equipment samples during its assessment, the cost of the stages of the life cycle of weapons and military equipment samples.

\section{References}

1. Chepkov I. B., Bilokur M. O., Sotnik V.V., Borohvostov I. V., Bondarchuk, M. V. (2019) Porlvnyalniy anallz sistem oboronnogo planuvannya v SShA ta UkraYinl. OzbroEnnya ta vlyskova tehnlka. № 3 (23). S. 9-18. DOI:
10.34169/2414-0651.2019.3(23).3-15.

2. Borohvostov I. V., Bilokur M.O. (2019) Isnuyuchl zv'yazki ta protirlchchya naukovometodichnogo zabezpechennya oboronnogo planuvannya ta shlyahlv osnaschennya 
ozbroEnnyam vlyskovih formuvan. Zbirnik nauk. prats TsNDI OVT ZS UkraYini Vip. 1 (72). S. 5-18.

3. Metodichnl rekomendatsIYi z flnansovoekonomlchnogo obGruntuvannya vartostl povnogo zhittEvogo tsiklu spromozhnostey z urahuvannyam printsiplv ta standartlv NATO. ZatverdzhenI MO UkraYini 02.06.2020.

4. Gary Jones, Erin Ryan, Tony White \& Jonathan Ritschel. Investigation into the Ratio of Operating and Support Costs to Life-Cycle Costs for DoD Weapon Systems. Defense ARJ. 2014, № 1 (21) pp. 442-464.

5. E. Ryan, D. Jacques, J. Colombi, C. Schubert. A Proposed Methodology to Characterize the Accuracy of Life Cycle Cost Estimates for DoD Programs. Procedia Computer Science 2012 №8 S. 361-369. DOI: 10.1016/j.procs.2012. 01.073.

6. Shtovba S.D. Proektirovanie nechetkih sistem sredstvami MATLAB. Moscow: Goryachaya liniya Telekom, 2007. $288 \mathrm{~s}$.

7. Takagi T., Sugeno M. Fuzzy identification of systems and its application to modeling and control // IEEE Transactions on Systems, Man and Cybernetics. Vol. 15. No 1. 1985. S. 116132.

8. Bellman R., Zade L. Prinyatie resheniy $v$ rasplyivchatyih usloviyah // Voprosyi analiza i protseduryi prinyatiya resheniy: $\mathrm{Sb}$. perevodov / Pod red. I.F. Shahnova. Moscow: Mir, 1976. S. 172-215.

9. Borisov A.N. Prinyatie resheniy na osnove nechetkih modeley. Primeryi modeley / A.N. Borisov, O.A. Krumberg, I.P. Fedorov. - Riga: Zinatne, 1990. $184 \mathrm{~s}$.

10. Asai K. Prikladnyie nechetkie sistemyi [per. $s$ yaponskogo] / Pod red. T. Terano, K. Asai, M.Sugeno. Moscow: Mir, 1993. 368 s.

11. Sugeno M. Industrial applications of fuzzy control. - Elsevier Science Pub. Co., 1985. $269 \mathrm{~s}$.

12. Bilokur M. O. Viblr vlastivostey OVT pld chas modelyuvannya vartostl stadly zhittEvogo tsiklu. Zb. nauk. pr. Kyiv: TsNDI OVT ZS Ukraini. 2019. № 4 (75). S. 112-118.

13. Bilokur M. O. (2020) Funktslonalne vidobrazhennya znachen vag $v$ shtuchnly neyronnly merezhl viznachenih vlastivostey pri otsInyuvannl alternativnih zrazklv ozbroEnnya. Ozbroennya ta vlyskova tehnlka. №2 (26). S. 20-31. DOI: 10.34169/24140651.2020.2(26).20-31.

14. Blaug M. Ekonomicheskaya myisl v retrospective. Moskva: Delo Ltd, 1994. $720 \mathrm{~s}$.

15. Viner Dzh. Kontseptsiya poleznosti $v$ teorii tsennosti i ee kritiki //Vehi ekonomicheskoy myisli. Teoriya potrebitelskogo povedeniya i sprosa. T. 1. Pod red. V.M. Galperina. SPb.: Ekonomicheskaya shkola, 2000.

16. Rotshteyn A. P. Intelektualnyie tehnologii: nechYotkie mnozhestva, geneticheskie algoritmyi, neyronnyie seti. Vinnitsa: "UNIVERSUM-Vinnitsya», 1999. $320 \mathrm{~s}$.

17. Averkin A. N., Batyirshin I. Z. i dr. Nechetkie mnozhestva $v$ modelyah upravleniya $i$ iskusstvennogo intellekta / Pod. red. D.A. Pospelova. Moscow: Nauka, 1986. $312 \mathrm{~s}$.

18. Bellman R.E., Zadeh L.A. (1970) Decisionmaking in fuzzy environment. Management Science. Vol.17. No.4. S. 141-164.

19. Melihov A. N., Bernshteyn L. S., Korovin S. Ya. Situatsionnyie sovetuyuschie sistemyi $\mathrm{s}$ nechYotkoy logikoy. Moscow: Nauka, 1990. $440 \mathrm{~s}$.

20. RekomendatsıYi z oboronnogo planuvannya na osnovl spromozhnostey $v$ MInlsterstvl oboroni UkraYini ta Zbroynih Silah UkraYini. Rezhim dostupu: Available from: https://www.mil.gov.ua/content/other/Rec ommendationson_CBP_120617.pdf.

21. Harrington, E. C. (1965) The desirable function. Industrial Quality Control. Vol. 21. No. 10. s. 494-498.

22. Samohvalov Y., Burba O. (2018) OtsInka efektivnostl naukovih I naukovo-tehnlchnih proektlv na osnovl uzagalnenoYi funktsIYi Harrlngtona. Sistemi upravllnnya, navlgats/Yi ta zv'yazku. Zblrnik naukovih prats. Poltava: PNTU, №. 4 (50). S. 77-85. DOI: 10.26906/SUNZ.2018.4.077.

23. Saati T. Prinyatie resheniy. Metod analiza ierarhiy. Moscow: Radio i svyaz, 1993. 278 s.

24. Leonenkov A. V. Nechetkoe modelirovanie $v$ srede MATLAB i fuzzyTECH. SPb.: BHV Peterburg, 2005. $736 \mathrm{~s}$.

25. Nor, P. I., Bilokur, M.O., Megey, K.V. (2019) 
Deyakl osoblivostl oboronnogo planuvannya rozvitku ozbroEnnya ta vlyskovoYi tehnlki Zbroynih Sil UkraYini na osnovl spromozhnostey. Zbirnik nauk. prats / TsNDI OVT ZS Ukrayini. № 3(74). s. 159-169.

26. Maryutin M. I. Ekonomika proizvodstva, ekspluatatsii i remonta vooruzheniya i tehniki. / M.I. Maryutin, S.Yu. Barkov, B.P.
Dolgopolov. Moskva: Voennaya akademiya bronetankovyih voysk im. Malinovskogo R.Y., 1989. $188 \mathrm{~s}$.

27. Nor P. I., Schipanskiy, P. V., Gogonyants, S. Yu. (2014) Metodika otsInki tehnlchnogo rlvnya zrazklv ozbroEnnya ta vlyskovoYi tehnlki. Sistemi ozbroennya I viyskova tehnika. № 3. s. 49-54. 